\title{
A Rapid Assessment of the Existence (or Survival) of Macro Fauna in Different Land Uses in Kween District of Mount Elgon
}

Siya Aggrey ( $\square$ siyaggrey@gmail.com )

Makerere University https://orcid.org/0000-0001-9627-656X

\section{Arthur Martin Kato}

Makerere University

\section{Anthony Egeru}

Makerere College

Kizza Charles Luswata

Ministry of Agriculture, Animal Industry and Fisheries

\section{Research note}

Keywords: macro fauna, abundance, diversity, land use

Posted Date: January 18th, 2021

DOl: https://doi.org/10.21203/rs.3.rs-146834/v1

License: (1) This work is licensed under a Creative Commons Attribution 4.0 International License. Read Full License 


\section{Abstract}

\section{Objective}

We explored the effect of different land uses on soil macro fauna species richness, abundance and diversity in Mount Elgon areas of Kween District, Uganda.

\section{Results}

Species richness was higher on the subsurface of the different land uses than belowground. A total of 647 individuals of both subsurface and belowground macro fauna were identified from the different land uses. Macro fauna abundance significantly varied across the five different land uses $(H=10.1, d . f .=4, p=0.04)$. The average diversity of the subsurface was higher (0.71) than that belowground (0.20). The highest diversity of macro fauna was found in the intercrop of maize-beans followed by natural vegetation. Maize monocrop had the least abundance and diversity of both surface crawling and belowground macro fauna. This could be due the diversity of food and living environments as mixed cropping introduces landscape heterogeneity that accommodates diverse organisms across different land use systems. This study recommends extended studies on taxonomy, ecology and management of soil macro fauna with detailed inventories on the functional groups across land use/cover types and evaluations of varied agricultural intensification regimes on abundance and diversity of soil above and below ground macro fauna.

\section{Introduction}

Several studies focus on above-ground flora and fauna species [1] [2]. Yet, below and above ground terrestrial ecosystems are interlinked, and the former potentially being more diverse but less explored than aboveground ecosystems [3]. Consequently, information on the diversity and abundance of belowground fauna in different landscapes is still insufficient especially in agriculture dependent countries like Uganda [2]. Due to such unsustainable land uses, pristine sub surface and below ground fauna has been lost. This is mainly attributed to intensified deforestation, forest degradation and unsustainable agricultural intensification or expansion [4]. For instance, the conversion of natural systems to modified agro-ecological systems is leading to shifts in species and, in extreme cases, local extinctions [5] [6] [7]. The loss of species inevitably has consequences on diversity, community structure and ecosystem processes [8] [9]. Equally, such changes have a more profound impact on soil properties and productivity [10] [11] [12]. Therefore, soil, and the macro fauna therein, is significantly important for ecological and economic reasons [13] [14] [15]. This justifies the need to measure and monitor macro fauna found in soil to support agriculture and functionality of related agroecosystems [16] [17].

\section{Methodology}

\section{Study area}

This study was undertaken in Kween District located at 01 25N, 34 31E found in the Mount Elgon agro-pastoral landscape. This highland district is located on the Northern slopes of Mount Elgon, at an average altitude of about 1,900 meters (6,200 Feet, above sea level). The slopes of Mt. Elgon are characterized by high and well-distributed rainfall (averaging 1,200 mm/year), high altitude with deep valleys (ranging from 700 to 2,800 meters above sea level), cool temperatures (averaging $17^{\circ} \mathrm{C}$ ), and predominantly volcanic soils. 
The major economic activity is subsistence farming and the major crops grown are; maize, beans, bananas, wheat, barley, and cowpeas. Whereas the soils of the area are perceived to be fertile, the area experiences a lot of inorganic fertilizer application. Farmers apply fertilizers due to the loose nature of the soils and the problem is aggravated by heavy rains. The study sites -Kaptum and Cheminy sub-counties- were selected because they have approximately three-quarters of the five main land uses considered for this study, which include grassland, maize mono-crop, natural forest, maize-beans, and coffee-banana land uses.

\section{Study design}

Within each land use, three plots were established and replicated $50 \mathrm{~m}$ apart. In each replicate, a sampling point for surface and below ground biota assessment was randomly selected. For surface and below biota assessment, a pitfall trap and monolith were installed respectively. The pitfall trap method was used to trap the surface crawling macro fauna, both diurnal and nocturnal ones. The pitfall method involved laying a 3liter bucket into the ground; the top leveling off with the surface. The surrounding area of the bucket was restored to its natural state. In the bucket, $50 \mathrm{ml}$ of $70 \%$ ethanol was added in order to demobilize and preserve the trapped organisms. The trapped organisms were removed every after 24 hours for 3 days and packed in well-labelled plastic bottles containing $70 \%$ ethanol. On the other hand, the monolith measuring $30 \times 30 \times 30 \mathrm{~cm}$ was used to collect belowground macro-organisms. The monolith was built into the soil but $8 \mathrm{~m}$ from the pitfall trap in each land use. All the soil within the monolith was put in clean and marked plastic bags. All the organisms collected using the pitfall trap and monolith were taken to Makerere University College of Agricultural and Sciences Soil Laboratory for analysis and macro fauna identification.

\section{Data analysis}

Data was analyzed using Real Statistica Statistical Software Package. Descriptive statistics were used to obtain frequencies and consequently species richness and abundance. Simpson's diversity index was used to compute the species diversity. Differences in diversity between subsurface and belowground macro fauna was tested using Wilcoxon's rank sum test whereas the Kruskal-Wallis $\mathrm{H}$ test was used to test differences in diversity between the different land uses [18].

\section{Results}

\section{Species richness of subsurface and belowground macro fauna in the different land uses}

Results revealed that macro fauna species richness was higher on the subsurface of the different land uses than belowground (Table 1). The maize-bean intercrop subsurface land use was richest of macro fauna whereas the grassland and maize monocrop land uses were both the least rich. Natural forest and maize monocrop land uses were richest with belowground macro fauna compared to the rest of the land uses. In all, the maize-bean intercrop land use had the highest species richness. Grassland had the lowest species richness. Table 1 details species richness of subsurface and belowground macro fauna in the different land uses.

\section{Abundance of subsurface and belowground macro fauna in the different land uses}


A total of 647 individuals of both subsurface and belowground macro fauna was identified from the different land uses. Table 1 shows the abundance of each macro fauna species identified from each land use. Macro fauna abundance was higher on the subsurface (75\%) than belowground (25\%). Overall, natural forests had the highest (44\%) macro fauna compared to the maize-bean intercrop (22\%), coffee-banana intercrop (14\%), grassland (13\%) and maize monocrop (8\%) land uses (Fig. 1). The macrofauna abundance significantly varied across the five different land uses $(H=10.1$, d.f. $=4, p=0.04)$.

\section{Diversity of subsurface and belowground macro fauna in the different land uses}

From Table 2, the average diversity of the subsurface was higher (0.71) than that belowground (0.20). Considering both the subsurface and belowground macro fauna, natural forests had the highest mean diversity index (0.65) followed by maize monocrop (0.58), maize-bean intercrop (0.42), coffee-banana intercrop (0.34) and least grasslands (0.32). The diversity of subsurface and belowground macro fauna significantly varied in the different land uses.

\section{Discussion}

\section{Effect of land-use management on surface crawling macro fauna diversity and abundance}

The existence of more macro organisms in mixed cropping systems can be linked to the enhanced physical characteristics of soil like temperature and moisture content [19] [20]. For the natural forest to have relatively less macrofauna could be due to the high level of degradation. Most forests in Uganda have been disturbed through anthropogenic and natural processes [21] [22] [23] [24]. Such disturbances can be linked to the less diversity of soil macro fauna in this study. Also, the short period during which this study was conducted could be one of the factors that influenced this result. This thus warrants for large scale studies to be conducted within such landscapes.

\section{Effect of land use practices on the diversity and abundance of belowground macro fauna}

Belowground macro fauna diversity and abundance was higher in a natural forest compared to the other four different land uses. There were only two orders of macro fauna (Megadrilacea and Coleoptera) trapped in the five different land-use systems. Conversion from natural to managed ecosystems generally induces a substantial decrease in soil carbon stock thus modifying belowground biodiversity [25] [26] [27] [28] which is likely to impact on aboveground biodiversity carbon storage, biomass and soil and may substantially alter carbon sink. It also may result in a change in the amount and quality of organic matter input to that particular ecosystem or, may alter the microclimate such as temperature, humidity and soil water significantly [29] [30] [31]. These changes undoubtedly affect the faunal composition and their activities in the soil [31] [32].

It has been reported in other studies that increased organic matter content positively affects the activity and existence of soil organisms [33]. This is because organic matter acts as energy sources for soil organisms to grow and strive. However, the results of this study indicate that macro fauna existence was negatively affected by 
carbon content which varies across different land-use systems. This could probably be due to the quality of carbon derived from the ecosystems by organisms as food. Plant residues are known to have different chemical compositions that influence their palatability to soil fauna [34] [35] [36]. Some organisms (e.g. termites) can digest several resistant compounds such as tannin-protein complexes and lignin [37] [38].

\section{Conclusion And Recommendations}

\section{Conclusion}

Natural forests and mixed legume crop ecosystems had the richest soil macro fauna diversity and abundance than other land uses. However, soil belowground macro fauna was less rich, abundant and diverse. It is important to improve below ground macro fauna as well as encourage mixed cropping systems. This will ensure soil functionality as well as agricultural productivity.

\section{Recommendations}

There is a need of more detailed studies to ascertain the effects of land uses on macro fauna in different land uses. This will be important in understanding which land uses could affect macro fauna presence and subsequently soil fertility. This will facilitate design of recommendations to farmers to ensure soil and biodiversity conservation

\section{Limitations}

The period during which this study was conducted was short to make sufficient recommendations. Future studies ought to enhance the rigor of the study through use of methods like randomized control trials.

\section{Declarations}

\section{Ethics approval and consent to participate}

Although the study did not require ethical approval, consent to undertake the study was obtained from the Kween District Natural Resources Department and farmers that agreed to collect soil samples from their gardens.

\section{Consent for publication}

Consent to publish was sought prior commencement of data collection.

\section{Availability of data and materials}

Data and materials are available on request from the corresponding author.

\section{Competing interests}

The authors declare no competing interests.

\section{Funding}

The study was privately funded by the corresponding author. 
AS designed the study, collected data and drafted the manuscript. AMK analyzed data and presented results. AE and KCL participated in interpretation of results and reviewing the manuscript.

\section{Acknowledgment}

We acknowledge the support of Kween district local government, farmers and the Makerere University College of Agricultural and Environmental Sciences for providing the lab space.

\section{References}

1. Wardle DA. The influence of biotic interactions on soil biodiversity. Ecology Letters. 2006.

2. Cameron EK, Martins IS, Lavelle P, Mathieu J, Tedersoo L, Bahram M, et al. Global mismatches in aboveground and belowground biodiversity. Conserv Biol. 2019.

3. Van Der Putten WH, Bardgett RD, De Ruiter PC, Hol WHG, Meyer KM, Bezemer TM, et al. Empirical and theoretical challenges in aboveground-belowground ecology. Oecologia. 2009.

4. Diaz S, Settele J, Brondizio E, Ngo HT, Gueze M, Agard J, et al. Summary for policymakers of the global assessment report on biodiversity and ecosystem services. 2019.

5. Perfecto I, Vandermeer J. The agroecological matrix as alternative to the land-sparing/agriculture intensification model. Proc Natl Acad Sci U S A. 2010.

6. Laurance WF, Sayer J, Cassman KG. Agricultural expansion and its impacts on tropical nature. Trends in Ecology and Evolution. 2014.

7. Altieri MA. Agroecology: The science of sustainable agriculture. 2018.

8. Valiente-Banuet A, Aizen MA, Alcántara JM, Arroyo J, Cocucci A, Galetti M, et al. Beyond species loss: The extinction of ecological interactions in a changing world. Funct Ecol. 2015.

9. Rybicki J, Hanski I. Species-area relationships and extinctions caused by habitat loss and fragmentation. Ecol Lett. 2013.

10. Nielsen UN, Ayres E, Wall DH, Bardgett RD. Soil biodiversity and carbon cycling: A review and synthesis of studies examining diversity-function relationships. European Journal of Soil Science. 2011.

11. Schindler DE, Hilborn R, Chasco B, Boatright CP, Quinn TP, Rogers LA, et al. Population diversity and the portfolio effect in an exploited species. Nature. 2010.

12. Lehmann A, Zheng W, Rillig MC. Soil biota contributions to soil aggregation. Nat Ecol Evol. 2017.

13. Schnitzer SA, Klironomos JN, HilleRisLambers J, Kinkel LL, Reich PB, Xiao K, et al. Soil microbes drive the classic plant diversity-productivity pattern. Ecology. 2011.

14. Paul BK, Vanlauwe B, Hoogmoed M, Hurisso TT, Ndabamenye T, Terano $Y$, et al. Exclusion of soil macrofauna did not affect soil quality but increased crop yields in a sub-humid tropical maize-based system. Agric Ecosyst Environ. 2015.

15. Culliney TW. Role of arthropods in maintaining soil fertility. Agric. 2013.

16. Slade EM, Riutta T. Interacting effects of leaf litter species and macrofauna on decomposition in different litter environments. Basic Appl Ecol. 2012. 
17. Kamau S, Barrios E, Karanja NK, Ayuke FO, Lehmann J. Soil macrofauna abundance under dominant tree species increases along a soil degradation gradient. Soil Biol Biochem. 2017.

18. StatSoft. Statistica version 13.0, data analysis software system. Tulsa: StatSoft. 2012.

19. Meisner A, Jacquiod S, Snoek BL, Ten Hooven FC, van der Putten WH. Drought legacy effects on the composition of soil fungal and prokaryote communities. Front Microbiol. 2018.

20. Wang J, Long T, Zhong Y, Li J, Zhang T, Feng Y, et al. Disentangling the influence of climate, soil and belowground microbes on local species richness in a dryland ecosystem of Northwest China. Sci Rep. 2017.

21. Mwavu EN, Witkowski ETF. Land-use and cover changes (1988-2002) around Budongo Forest Reserve, NW Uganda: Implications for forest and woodland sustainability. L Degrad Dev. 2008.

22. Chapman CA, Lambert JE. Habitat alteration and the conservation of African primates: Case study of Kibale National Park, Uganda. Am J Primatol. 2000.

23. Nakakaawa CA, Vedeld PO, Aune JB. Spatial and temporal land use and carbon stock changes in Uganda: Implications for a future REDD strategy. Mitig Adapt Strateg Glob Chang. 2011.

24. Banana A, Vogt N, Bahati J, Gombya-Ssembajjwe W. Decentralized governance and ecological health: Why local institutions fail to moderate deforestation in Mpigi district of Uganda. Sci Res Essays. 2007.

25. Don A, Schumacher J, Freibauer A. Impact of tropical land-use change on soil organic carbon stocks - a metaanalysis. Global Change Biology. 2011.

26. Bouchoms S, Wang Z, Vanacker V, Doetterl S, Van Oost K. Modelling long-term soil organic carbon dynamics under the impact of land cover change and soil redistribution. Catena. 2017.

27. van Noordwijk M, Rahayu S, Hairiah K, Wulan YC, Farida a, Verbist B. Carbon stock assessment for a forestto-coffee conversion landscape in Sumber-Jaya (Lampung, Indonesia): from allometric equations to land use change analysis. Sci China Ser C-Life Sci. 2002.

28. Andriamananjara A, Hewson J, Razakamanarivo H, Andrisoa RH, Ranaivoson N, Ramboatiana N, et al. Land cover impacts on aboveground and soil carbon stocks in Malagasy rainforest. Agric Ecosyst Environ. 2016.

29. Khasanah N, van Noordwijk M, Ningsih H, Rahayu S. Carbon neutral? No change in mineral soil carbon stock under oil palm plantations derived from forest or non-forest in Indonesia. Agric Ecosyst Environ. 2015.

30. Davidson EA, Janssens IA. Temperature sensitivity of soil carbon decomposition and feedbacks to climate change. Nature. 2006.

31. Curiel Yuste J, Baldocchi DD, Gershenson A, Goldstein A, Misson L, Wong S. Microbial soil respiration and its dependency on carbon inputs, soil temperature and moisture. Glob Chang Biol. 2007.

32. Lambers H, Mougel C, Jaillard B, Hinsinger P. Plant-microbe-soil interactions in the rhizosphere: An evolutionary perspective. Plant and Soil. 2009.

33. Lehmann J, Rillig MC, Thies J, Masiello CA, Hockaday WC, Crowley D. Biochar effects on soil biota - A review. Soil Biology and Biochemistry. 2011.

34. Cleveland CC, Reed SC, Keller AB, Nemergut DR, O’Neill SP, Ostertag R, et al. Litter quality versus soil microbial community controls over decomposition: A quantitative analysis. Oecologia. 2014.

35. Thoms C, Gattinger A, Jacob M, Thomas FM, Gleixner G. Direct and indirect effects of tree diversity drive soil microbial diversity in temperate deciduous forest. Soil Biol Biochem. 2010.

36. Eskelinen A, Stark S, Männistö M. Links between plant community composition, soil organic matter quality and microbial communities in contrasting tundra habitats. Oecologia. 2009. 
37. Ushio M, Kitayama K, Balser TC. Tree species effects on soil enzyme activities through effects on soil physicochemical and microbial properties in a tropical montane forest on Mt. Kinabalu, Borneo. Pedobiologia (Jena). 2010.

38. Ladygina N, Hedlund K. Plant species influence microbial diversity and carbon allocation in the rhizosphere. Soil Biol Biochem. 2010.

\section{Tables}

Table 1

Species richness and abundance of subsurface and belowground macro fauna in the different land uses

\begin{tabular}{|c|c|c|c|c|c|c|}
\hline \multirow{2}{*}{$\begin{array}{l}\text { Macro fauna } \\
\text { type }\end{array}$} & \multicolumn{5}{|l|}{ Land use } & \multirow{2}{*}{$\begin{array}{l}\text { Species } \\
\text { richness } \\
\text { of } \\
\text { macro } \\
\text { fauna } \\
\text { type }\end{array}$} \\
\hline & $\begin{array}{l}\text { Coffee- } \\
\text { banana } \\
\text { intercrop }\end{array}$ & Grassland & $\begin{array}{l}\text { Maize } \\
\text { monocrop }\end{array}$ & $\begin{array}{l}\text { Maize-bean } \\
\text { intercrop }\end{array}$ & $\begin{array}{l}\text { Natural } \\
\text { Forest }\end{array}$ & \\
\hline Sub surface & $\begin{array}{l}\text { Coleoptera } \\
\text { (27) } \\
\text { Hymenoptera } \\
\text { (10) Isoptera } \\
\text { (5) } \\
\text { Lepidoptera } \\
\text { (11) }\end{array}$ & $\begin{array}{l}\text { Coleoptera } \\
\text { (13) } \\
\text { Lepidoptera } \\
\text { (19) } \\
\text { Orthoptera } \\
\text { (32) }\end{array}$ & $\begin{array}{l}\text { Hymenoptera } \\
\text { (8) } \\
\text { Lepidoptera } \\
\text { (13) } \\
\text { Orthoptera } \\
\text { (4) }\end{array}$ & $\begin{array}{l}\text { Coleoptera } \\
\text { (15) } \\
\text { Diplopoda (5) } \\
\text { Hemiptera } \\
\text { (19) } \\
\text { Hymenoptera } \\
\text { (12) Isoptera } \\
\text { (22) } \\
\text { Lepidopera } \\
\text { (24) } \\
\text { Orthoptera } \\
\text { (23) }\end{array}$ & $\begin{array}{l}\text { Coleoptera } \\
\text { (42) } \\
\text { Diplopoda } \\
\text { (17) } \\
\text { Hymenoptera } \\
\text { (28) Isoptera } \\
\text { (58) } \\
\text { Lepidopera } \\
\text { (61) } \\
\text { Orthoptera } \\
\text { (17) }\end{array}$ & 7 \\
\hline Belowground & $\begin{array}{l}\text { Megadrilacea } \\
\text { (39) }\end{array}$ & $\begin{array}{l}\text { Megadrilacea } \\
\text { (18) }\end{array}$ & $\begin{array}{l}\text { Megadrilacea } \\
(11) \\
\text { Coleoptera } \\
(13)\end{array}$ & $\begin{array}{l}\text { Megadrilacea } \\
\text { (20) }\end{array}$ & $\begin{array}{l}\text { Megadrilacea } \\
(35) \\
\text { Coleoptera } \\
(26)\end{array}$ & 2 \\
\hline $\begin{array}{l}\text { Species } \\
\text { richness of } \\
\text { land use }\end{array}$ & 5 & 3 & 5 & 8 & 7 & \\
\hline
\end{tabular}

Table 2

Simpson's Diversity Index of subsurface and belowground macro fauna for the different land uses

\begin{tabular}{|c|c|c|c|c|c|}
\hline \multirow{2}{*}{$\begin{array}{l}\text { Macro fauna } \\
\text { type }\end{array}$} & \multicolumn{5}{|l|}{ Land use } \\
\hline & $\begin{array}{l}\text { Coffee-banana } \\
\text { intercrop }\end{array}$ & Grassland & $\begin{array}{l}\text { Maize } \\
\text { monocrop }\end{array}$ & $\begin{array}{l}\text { Maize-bean } \\
\text { intercrop }\end{array}$ & $\begin{array}{l}\text { Natural } \\
\text { Forest }\end{array}$ \\
\hline Subsurface & 0.67 & 0.63 & 0.63 & 0.84 & 0.8 \\
\hline Belowground & 0 & 0 & 0.52 & 0 & 0.5 \\
\hline
\end{tabular}

\section{Figures}




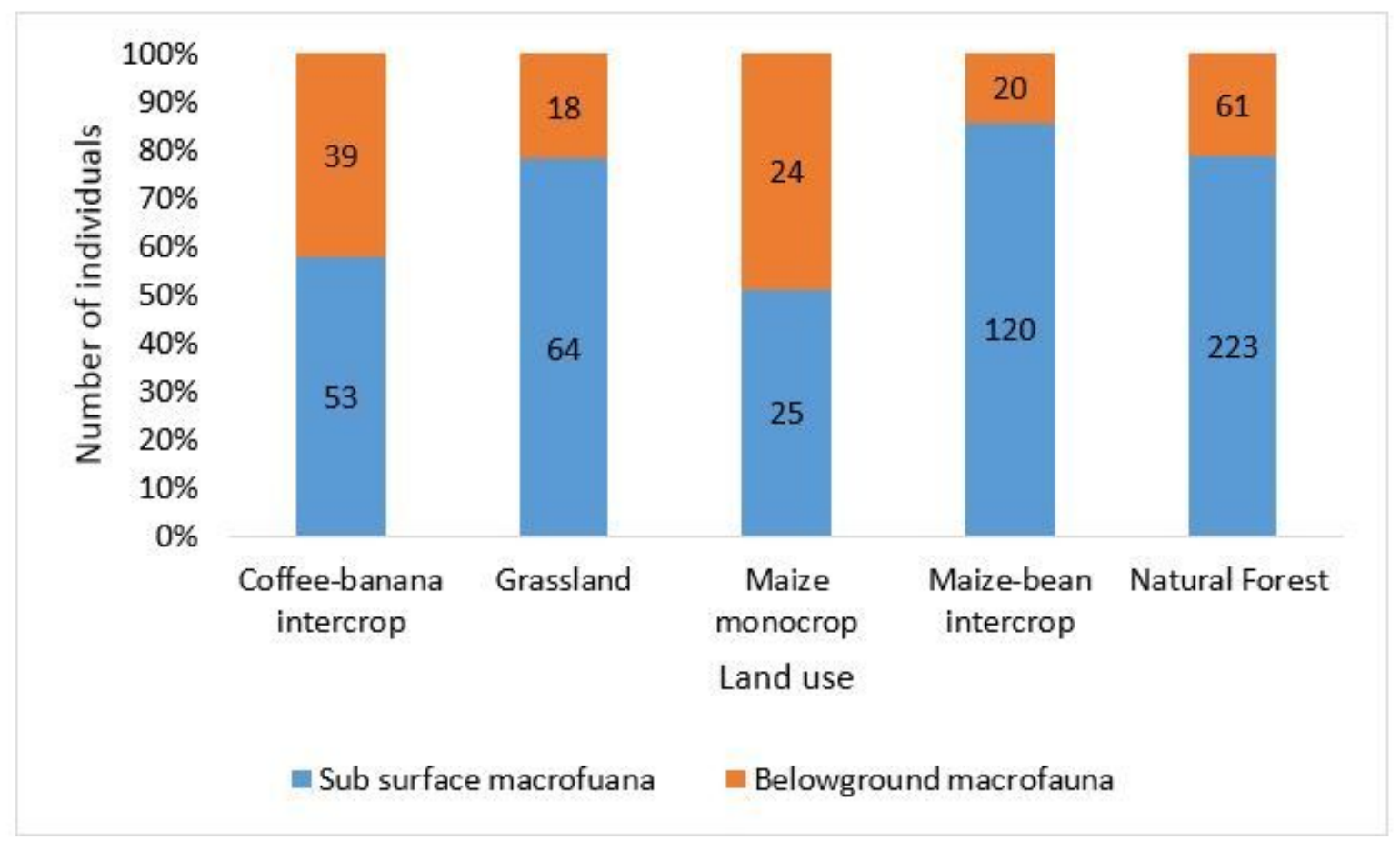

\section{Figure 1}

Abundance of subsurface and belowground macro fauna in the different land uses 